BMJ Nutrition,

Prevention \& Health

\section{Effect of milk supplementation on the status of micronutrients among rural school children aged 5-19 years in a tribal predominating district of India}

To cite: Kumar C, Rana RK, Kumar M, et al. Effect of milk supplementation on the status of micronutrients among rural school children aged 5-19 years in a tribal predominating district of India. BMJ Nutrition, Prevention \& Health 2021;4:e000223. doi:10.1136/ bmjnph-2020-000223

${ }^{1}$ Department of Community Medicine, Sheikh Bhikhari Medical College, Hazaribagh, Jharkhand, India ${ }^{2}$ Department of Preventive and Social Medicine, Shaheed Nirmal Mahato Medical College, Dhanbad, Jharkhand, India ${ }^{3}$ Department of Preventive and Social Medicine, Rajendra Institute of Medical Sciences, Ranchi, Jharkhand, India

Correspondence to Dr Dewesh Kumar, Rajendra Institute of Medical Sciences, Ranchi, Jharkhand, India; dr.dewesh@gmail.com

Received 18 December 2020 Accepted 25 October 2021 Published Online First 3 November 2021

\section{ABSTRACT}

Background In the tribal state of Jharkhand, there have been very few studies on micronutrient deficiency and how it is addressed among school children. This study was conceived and undertaken to assess the effect of milk supplementation on the micronutrient status of school children.

Design A comparative observational study was conducted among school children of a tribal district in India during 2017-2018. Two groups of schools/clusters were randomly selected, one with milk supplementation and the other without supplementation. A total of 318 children from the two groups of schools were recruited for biochemical analysis of certain micronutrients, such as calcium, vitamin $D$, vitamin $B_{12}$ and iron (haemoglobin level), using cluster random sampling. Data were analysed using SPSS V.20.0 software, and multiple logistic regression analysis was done to determine the predictors of serum calcium and vitamin $B_{12}$ level among school children.

Results Almost all children from both groups had vitamin $D$ deficiency. A higher risk of lower serum vitamin $B_{12}$ level (OR 2.59, 95\% Cl 1.61 to 4.16) and calcium level (OR $3.36,95 \% \mathrm{Cl} 1.74$ to 6.49 ) was observed in children of the control group. The difference in the proportion of anaemia in the two study groups was found to be statistically insignificant. Milk consumption was found to be the only significant predictor of normal vitamin $\mathrm{B}_{12}$ and calcium level in the present study.

Conclusions In this study, it was concluded that milk consumption may help in improving the calcium and vitamin $\mathrm{B}_{12}$ status of school children of a tribal state, whereas it does not have any significant effect on vitamin D level.

\section{INTRODUCTION}

India contributes to one-third of the total number of stunted children under 5 years of age globally, ${ }^{1}$ and this malnutrition continues to exist among school children and adolescents despite various ongoing nutrition programmes in the country. Malnutrition results in an underdeveloped brain, with longlasting harmful consequences of diminished
What this paper adds

- In this study, fortified milk has helped in improving calcium and vitamin $\mathrm{B}_{12}$ amongst school children.

- Vitamin $\mathrm{D}$ levels in the school children were very low in the study subjects, amost all were vitamin D deficient.

- Milk has improved the status of anemia in the study subjects but was not statistically significant.

mental ability and learning capacity, poor school performance, and increased risk of nutrition-related chronic diseases such as diabetes, hypertension and obesity in the future. ${ }^{2-4}$ Not only macronutrients but micronutrients also significantly contribute to problems related to undernutrition. These problems seem to be more relevant in developing countries like India, where a significant proportion of the population are still unable to meet their hunger needs.

In the last seven decades, there have been several initiatives by the Government of India to check for nutritional problems across various age groups, but the problem of both macronutrient and micronutrient deficiencies remains a serious concern in the country. ${ }^{5}$ Among many nutrition improvement measures in the country, the midday meal scheme is one such ubiquitous programme aimed to supplement the nutritional needs of school children and increase overall school attendance. State governments have got the flexibility to decide the menu for mid-day meal programmes and preferably select local food items rich in macronutrients and micronutrients for school children. The government of Jharkhand has always remained open for suggestions and innovations which may improve the nutritional status of school children. Experts from 
different sectors proposed that the government keep milk as an option in mid-day meals considering its wide acceptability and availability as well as established benefits in improving nutrition.

Milk is a food item enriched with good-quality nutrients. There is evidence in the literature way back in 1929 of using milk as a food supplement for school children to improve overall growth in height and weight. ${ }^{7}$ Over the years, studies across the globe have established the fact that milk is an important source of nutrition and has a significant role in improving the health of school children. ${ }^{8-12}$ Milk and dairy products contain various vitamins and minerals which contribute to the different vital functions of the body. There are macroelements (calcium $(\mathrm{Ca})$, magnesium $(\mathrm{Mg})$, sodium $(\mathrm{Na})$, potassium $(\mathrm{K})$, phosphorus $(\mathrm{P})$ and chlorine $(\mathrm{Cl})$ ) and oligoelements (iron $(\mathrm{Fe})$, copper $(\mathrm{Cu})$, zinc $(\mathrm{Zn})$ and selenium $(\mathrm{Se})$ ) in the mineral fraction of milk. Almost all lipophilic (A, D, E and $\mathrm{K}$ ) and hydrophilic (B complex and C) vitamins are also present in the fat and aqueous fraction of milk. Evidence also suggests milk as one of the contributors to increased uptake of nutrients in children. ${ }^{13-15}$

Severe micronutrient deficiencies usually result in typical deficiency diseases such as night blindness, rickets, hypocalcaemic tetany, etc. However, milder forms of micronutrient deficiencies are much more common and frequently go unnoticed. The detrimental effects of such suboptimal status are not clear, but the assumption persists that this subclinical deficiency leads to incessant metabolic and pathological changes in the body over a period of time. ${ }^{16}$ Similar condition also holds true for macronutrient deficiency in children. Considering macronutrient and micronutrient deficiencies in rural school children, the government of Jharkhand, in collaboration with Jharkhand Milk Federation (JMF), launched a nutrition supplement initiative called 'Gift Milk Programme' in the Latehar district of Jharkhand, India. In this new initiative, $200 \mathrm{~mL}$ fortified (with vitamin A and vitamin D) flavoured milk were provided on all working days to 36 schools catering to 14000 students during 2017-2018. In consonance with the programme, an evaluation research was designed to study the effects of milk supplementation on the health of school children. The present paper is an attempt to assess the effect of milk supplementation on the status of selected micronutrients among school children of Jharkhand.

\section{METHODOLOGY}

The study was conducted in selected government schools of homogenous blocks in the Latehar district of Jharkhand from October 2017 to January 2019. This was a comparative, school-based observational study using multistage random sampling method. In the first stage, all government schools of the Latehar district were listed and were further divided into programmatic/intervention schools and control schools. In the second stage, eight schools from each group were randomly selected using cluster random sampling. Each school was considered a cluster and equal numbers of subjects were recruited from each cluster. In the third stage, 60 students from each selected school were chosen as study subjects. The students were selected using systematic random sampling and the male to female ratio was maintained at 1:1. In this way a minimum of $480 \mathrm{school}$ children were selected from each group. Selection of schools, sample size determination and the number of students from each school were in accordance with the statistical methods and the planned steps of multistage random sampling. A total sample size of 960 was studied considering the prevalence of malnutrition (40\%), relative precision (10\%), 95\% CI and design effect (1.5) for this study. ${ }^{17}$ Before deciding on the schools, utmost care was taken to ensure that both the intervention and the control schools were substantially separated from each other to avoid spillover effect in the group as well as other operational issues. Only 20 consecutive children from each school (male to female ratio: $1: 1)$ were selected from the initially sampled group of 60 students. From these children, $5 \mathrm{~mL}$ venous blood samples were drawn from the median cubital vein in the antecubital fossa using a vacutainer under all aseptic conditions. Thus 33\% (320 out of 960) of the students were evaluated for various micronutrients considering limitations in resources, timing, and ethical and statistical considerations. Two samples were discarded, one due to less quantity and the other due to mishandling, and hence micronutrient evaluation was done for 318 samples. Therefore, the findings of the present study are limited to 318 school children only (figure 1).

This research was part of a longitudinal study which was divided into three phases: preintervention/baseline, intervention/programmatic and postintervention/ endline assessment. During the preintervention phase, baseline data were collected from the study subjects. These comprised sociodemographic information, health status, anthropometric measurements and haemoglobin level. In the programmatic phase, school children from the programmatic/intervention schools were given 200 $\mathrm{mL}$ fortified flavoured milk in disposable packs during the break period of each working day for 1 year (from December 2017 to November 2018). The milk was provided by JMF in disposable packs under cold chain to all schools. Its uninterrupted supply, cold chain and quality assurance were continuously monitored by a third party under the guidance and supervision of the National Dairy Development Board Foundation for Nutrition in Anand, India. In the postintervention/endline assessment phase, data on sociodemographic profile, health status and anthropometric measurements of study participants were again collected. Apart from this, the blood samples of 20 children from each school/cluster were taken to evaluate the level of serum vitamin $\mathrm{B}_{12}$ (Serum Chemiluminescent Micro Particle Immunoassay), serum calcium (Serum/Arsenazo III), serum vitamin D (Serum Chemiluminescent Micro Particle Immunoassay) and haemoglobin (Automated Blood Cell Counter; Beckman 


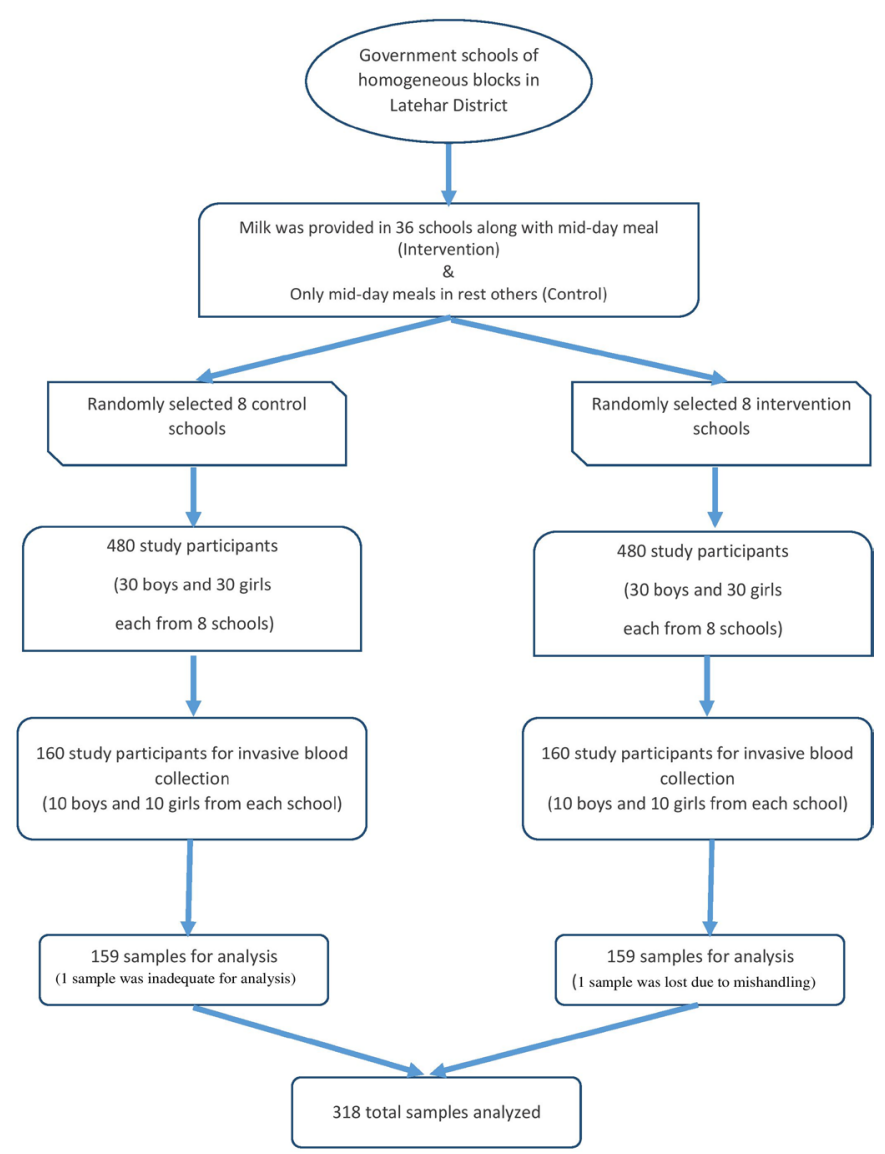

Figure 1 Flow chart showing the selection of study participants for the study.

Coulter). The blood was sampled only once during the study and was done after 1 year of intervention in a span of 20 days in December 2018 from all the control and intervention schools. For data analysis, normal level of serum calcium was considered at $8.8-10.6 \mathrm{mg} / \mathrm{dL}$, for vitamin $\mathrm{B}_{12}$ 187-883 $\mathrm{pg} / \mathrm{mL}$ and for vitamin $\mathrm{D}$ 30-100 $\mathrm{ng} / \mathrm{mL}$. This was in accordance with the standard laboratory values of the National Accredited Board of Laboratories testing laboratory and equipment used. Anaemia among the study subjects was classified following the WHO guidelines according to age. ${ }^{18}$ Anaemia was taken as a proxy indicator of iron status. The investigators in our team carried out all research activities from data collection to data analysis.

\section{Data analysis}

Data management was done in Microsoft Excel V.2016 and statistical analysis in SPSS V.20.0. Mean and SD were used to express quantitative data, while proportions and percentages were used for qualitative data. Regression analysis was done to understand the predictors, and the association between variables was interpreted using OR. The study was done after taking consent and assent from the parents/guardians and children (adolescents), respectively. The school authorities were informed in advance about the research and permission was sought to conduct the study.

\begin{tabular}{|c|c|c|c|}
\hline \multicolumn{2}{|c|}{$\begin{array}{l}\text { Sociodemographic } \\
\text { characteristics }\end{array}$} & \multirow{2}{*}{$\begin{array}{l}\text { Intervention, } \mathbf{n} \\
(\%)(\mathrm{n}=159)\end{array}$} & \multirow{2}{*}{$\begin{array}{l}\begin{array}{l}\text { Control, } n \\
(\%)(n=159)\end{array} \\
78(49.1)\end{array}$} \\
\hline Gender & Male & & \\
\hline & Female & $79(49.7)$ & $81(50.9)$ \\
\hline \multirow[t]{2}{*}{ Age (years) } & Up to 10 & $12(7.5)$ & $3(1.9)$ \\
\hline & $11-19$ & 147 (92.5) & $156(98.1)$ \\
\hline \multirow[t]{4}{*}{ Caste } & Upper & $4(2.5)$ & $10(6.3)$ \\
\hline & OBC & $78(49.1)$ & $49(30.8)$ \\
\hline & SC & 35 (22.0) & $29(18.2)$ \\
\hline & ST & $42(26.4)$ & $71(44.7)$ \\
\hline \multirow[t]{4}{*}{ Religion } & Hindu & $111(69.8)$ & $81(50.9)$ \\
\hline & Muslim & $14(8.8)$ & $9(5.7)$ \\
\hline & Christian & $14(8.8)$ & $1(0.6)$ \\
\hline & Others ${ }^{*}$ & 20 (12.6) & $68(42.8)$ \\
\hline \multirow[t]{2}{*}{ Ethnicity } & Non-tribal & 117 (73.6) & $87(54.7)$ \\
\hline & Tribal & $42(26.4)$ & $71(44.7)$ \\
\hline \multirow[t]{3}{*}{ Birth order } & First & $41(25.8)$ & $42(26.4)$ \\
\hline & Second & $44(27.7)$ & $44(27.7)$ \\
\hline & Third or higher & $74(46.5)$ & $73(45.9)$ \\
\hline
\end{tabular}

*Others include Sarna, a local religion of Jharkhand.

OBC, other backward caste; SC, scheduled caste; ST, scheduled tribe.

\section{RESULTS}

In the present study, 960 children were included and 318 were chosen for biochemical analysis of micronutrient status. The gender distribution in both groups was similar and nearly equal. Majority of the subjects belonged to the 11-19 years age group. Socially, only a few of them were from the upper caste and the rest were from other backward caste and scheduled caste and tribes. There were more subjects from the ethnic tribes in the control group (44.7\%) compared with the intervention group $(26.4 \%)$. The birth order of the subjects was similar in both groups (table 1).

Nearly all subjects in both groups were found to have low vitamin $\mathrm{D}$ level. Serum vitamin $\mathrm{B}_{12}$ deficiency and serum calcium deficiency were more common among subjects of the control group. Using bivariate regression analysis, it was found that after milk consumption the chances of having normal serum vitamin $\mathrm{B}_{12}$ level were more than two times (OR 2.59, $95 \%$ CI 1.61 to 4.16 ) and that of normal serum calcium level more than three times (OR 3.36, 95\% CI 1.74 to 6.49). Moreover, the mean serum vitamin $\mathrm{B}_{12}$ level and serum calcium level were also significantly higher among the subjects of the intervention group compared with the subjects of the control group. Although anaemia was found to be more common among the subjects of the control group, increased risk of anaemia was statistically not significant (OR 1.54, 95\% CI 0.97 to 2.45 ) (table 2 ).

Logistic regression analysis was done for predictors of normal serum calcium level and normal serum vitamin 
Table 2 Bivariate regression analysis of the status of micronutrients among subjects from both groups ( $\mathrm{N}=318)$

\begin{tabular}{lllll} 
Micronutrient variables & & Intervention, $\mathbf{n}(\%)$ & Control, $\mathbf{n}(\%)$ & OR (95\% Cl) \\
\hline Serum vitamin $D^{*}$ & Low & $158(99.4)$ & $158(99.4)$ & - \\
Serum vitamin $B_{12} \dagger$ & Normal & $1(0.6)$ & $1(0.6)$ & $2.59(1.61$ to 4.16$)$ \\
Serum calcium $\ddagger$ & Normal & $40(25.2)$ & $85(53.5)$ & $3.56(1.74$ to 6.49$)$ \\
Anaemia§ & Low & $119(74.8)$ & $39(24.5)$ & $1.54(0.97$ to 2.45$)$ \\
& Normal & $14(8.8)$ & $120(75.5)$ & \\
\hline
\end{tabular}

*Mean $( \pm S D)$ vitamin D level was $16.62( \pm 4.73)$ and $16.34( \pm 4.99)$ in the intervention and control group, respectively.

†Mean $\left( \pm\right.$ SD) vitamin $B_{12}$ level was $266.27( \pm 113.99)$ and $225.01( \pm 114.54)$ in the intervention and control group, respectively.

$\neq$ Mean $( \pm$ SD) serum calcium level was $9.44( \pm 0.64)$ and $9.10( \pm 0.73)$ in the intervention and control group, respectively.

§Mean $( \pm \mathrm{SD})$ serum haemoglobin level was $12.14( \pm 1.28)$ and $12.19( \pm 1.20)$ in the intervention and control group, respectively.

$\mathrm{B}_{12}$ level among the study subjects. Vitamin $\mathrm{D}$ and haemoglobin levels (anaemia) were statistically insignificant across the two groups and hence were not included in the regression analysis. The main predictor tested was milk consumption by study subject, gender, ethnicity and birth order. For normal serum calcium level, milk consumption was found to be an important factor (OR $3.27,95 \%$ CI 1.67 to 6.39 ). Other factors were not significant for normal serum calcium level. Similarly, for normal vitamin $\mathrm{B}_{12}$ level, milk consumption was also found to be an important predictor (OR 2.95, 95\% CI 1.80 to 4.85 ). It was also noted that tribal ethnicity was found to be associated with risk of low vitamin $\mathrm{B}_{12}$ level (OR 0.54, 95\% CI 0.32 to 0.91 ) in comparison with non-tribal ethnicity. Other factors were significantly not associated with serum vitamin $\mathrm{B}_{12}$ level (table 3).

\section{DISCUSSION}

Micronutrient and macronutrient deficiencies in the Indian population are rampant despite the country being one of the major producers of milk, fruits, vegetables and grains. ${ }^{19}$ While there are many studies on iron deficiency, vitamin A deficiency and iodine deficiency, there are relatively fewer studies on vitamin $\mathrm{D}$, vitamin $\mathrm{B}_{12}$ and serum calcium status in
India especially among school children. ${ }^{4}$ The current study is unique in the sense that there have been no studies on the studied micronutrients in a tribal population.

The present study was done in children and adolescent age groups and assessed the effect of milk supplementation on their vitamin $\mathrm{D}$, serum calcium, vitamin $\mathrm{B}_{12}$ and haemoglobin status. Almost all children of both groups (99.4\%) have low level of vitamin D in their blood. Many Indian community-based studies have shown a higher prevalence (50\%-94\%) of vitamin D deficiency among their study subjects of different age groups and gender. ${ }^{20-23}$ The finding of the present study on vitamin D status is in concordance with the study done by Kapil $e t a t^{24}$ in Shimla in a similar age group (6-18 years) which has shown a prevalence of vitamin $\mathrm{D}$ deficiency of $93 \%$. However, studies done by Basu et $a t^{25}$ among subjects in the 1-16 years age group in 2015 and Angurana et $a t^{26}$ among subjects in the 3 months-12 years age group in 2014 have reported a prevalence of vitamin D deficiency of $52.9 \%$ and $40.2 \%$, respectively. However, these two studies were done in a hospital setting and there is a possibility of higher number of subjects of better socioeconomic status. These could be the possible reasons for the lower prevalence of vitamin D deficiency in their studies. Although milk contains varying levels of vitamin A, D and

Table 3 Logistic regression analysis of predictors of normal serum calcium and serum vitamin $B_{12}$ status among the study subjects

\begin{tabular}{|c|c|c|c|c|c|}
\hline \multirow[b]{2}{*}{ Variables } & & \multicolumn{2}{|c|}{ Serum calcium } & \multicolumn{2}{|c|}{ Vitamin $B_{12}$} \\
\hline & & OR & $95 \% \mathrm{Cl}$ of $\mathrm{OR}$ & OR & $95 \% \mathrm{Cl}$ of $\mathrm{OR}$ \\
\hline Milk consumption & No & 1 & & 1 & \\
\hline \multirow[t]{2}{*}{ Gender } & Male & 1 & & 1 & \\
\hline & Female & 0.79 & 0.42 to 1.45 & 0.99 & 0.61 to 1.60 \\
\hline \multirow[t]{3}{*}{ Birth order } & First & 1 & & 1 & \\
\hline & Second & 1.32 & 0.58 to 2.98 & 1.13 & 0.60 to 1.64 \\
\hline & Third & 1.01 & 0.47 to 2.18 & 0.81 & 0.45 to 1.41 \\
\hline
\end{tabular}


E, milk itself has not been considered an important dietary source of vitamin D. ${ }^{27}{ }^{28}$ Also, in the present study, there was no significant difference in vitamin $\mathrm{D}$ level in the subjects of both groups and nothing can be attributed to fortified milk.

Vitamin $B_{12}$ is an important micronutrient for the human body, and the main sources of vitamin $B_{12}$ for humans are animal products. ${ }^{29}$ Among animal products, milk is considered an important source of vitamin $B_{12}$ for human beings, and $250 \mathrm{~mL}$ cow milk may fulfil the $50 \%$ recommended dietary allowance of vitamin $\mathrm{B}_{12} .{ }^{30} 31$ The current study found that vitamin $\mathrm{B}_{12}$ level was better among children who regularly consumed milk for 1 year than those who did not consume milk. Similar finding was reported by a study done by Naik $e t a l^{32}$ in 2013 in India. Other studies across the world have also found that bioavailability of vitamin $\mathrm{B}_{12}$ in milk is better than fish or other sources. ${ }^{33} 34$ Since pure vegetarians are more likely to be deficient in vitamin $\mathrm{B}_{12}$, addition of milk in their diet can reduce this deficiency to a certain extent. This nutritional intervention can be helpful for children of lower socioeconomic status in India who are unable to consume milk daily. Unpublished data of this study also show that less than $10 \%$ of children were consuming milk on a regular basis and few $(3 \%)$ children have never tasted milk in their lifetime, depicting the vulnerability of their dietary and nutritional status.

Calcium is another vital micronutrient for the human body, required for many biochemical processes. Among various dietary sources, milk, especially cow milk, is an important source of readily available calcium. ${ }^{35}$ Apart from the concentration, the bioavailability and absorption of calcium from milk are better as compared with cereals and green leafy vegetables. ${ }^{36-38}$ Our study also reported that children who consumed milk had significantly better calcium level in their body. Other studies in the world have also highlighted the beneficial effect of milk on calcium level in the body and its overall effect on bone in humans. ${ }^{39} 40$

Many published literature supports the view that consumption of milk is associated with iron deficiency anaemia, especially among infants, toddlers and young children. The main possible mechanism for this association is poor availability of iron and ascorbic acid in milk or dairy products and decreased absorption of iron from other food items when consumed with milk. ${ }^{41-44}$ Another possible mechanism for this relation between milk consumption and iron deficiency anaemia is the occurrence of microhaemorrhages in the gut especially among infants. ${ }^{41}{ }^{45}$ Contrary to this evidence, the present study suggests that consumption of milk is associated with less occurrence of anaemia. In this study, the proportion of subjects with anaemia was higher among the control group compared with the intervention group. There are schools of thoughts which opine that calcium does not affect iron absorption in the long term and that absorption of iron from cereal-based diets in human body is unaffected by the addition of milk. ${ }^{4647}$ The researchers in our study also highlighted the fact that anaemia in Indian children is not only due to iron deficiency, but may also be due to protein deficiency owing to poor quality of protein, based on earlier evidence. ${ }^{48}$ Milk supplementation in the intervention group may be providing goodquality protein along with other nutrients, helping in the better synthesis of haemoglobin, which can be the reason for the lower prevalence of anaemia in the intervention group. The difference in proportion in the two groups of the current study was statistically insignificant, and needs to be confirmed by other assays and warrants further research to support the viewpoint.

\section{CONCLUSION}

From this study, it can be concluded that milk consumption may help in meeting the calcium and vitamin $B_{12}$ requirements of school children of a tribal state, whereas it does not have any significant effect on vitamin $\mathrm{D}$ level. Overall vitamin D levels in the study population are abysmally low, and providing fortified milk with the present amount of vitamin $\mathrm{D}$ fortification for 1 year alone may not be sufficient to meet the daily requirements and compensate for the existing low levels of vitamin D. Haemoglobin levels have improved with fortified milk supplementation, but the difference in the study groups is not statistically significant. Hence, other diet and lifestyle interventions may be needed to combat anaemia among school children.

There were some limitations to the present study. At baseline, we did not collect blood samples for biochemical assessment, which could have given a better picture of the effect of milk on micronutrients. The smaller sample size due to financial and time constraints was a major limitation of this study. The intervention phase of 1-year duration may be another limitation of the study and a longer duration could present a clear picture of the long-term effects on different nutrients. Nevertheless, the present study has shown a means to improve the status of certain micronutrients among children in remote areas and of lower socioeconomic status. A detailed study with a larger sample size and longer duration can pave the way for provision of milk supplementation for school children.

Acknowledgements We are grateful to all the postgraduates and lab technicians of PSM, RIMS Ranchi for their assistance in carrying out the study in the selected schools of Latehar, India.

Contributors DK, CK, AK, RKR and VK conceived the study and were involved in designing the study. VS and MK guided and supervised the data collection. SBS and NK helped in analysing the data and provided input in the preparation of the manuscript. CK and DK prepared and aligned the manuscript. All the authors read, critically discussed and approved the final manuscript. DK is the guarantor of the study

Funding The NDDB Foundation for Nutrition (NFN), Anand, India, and the Rural Electrification Corporation Foundation (REC) New Delhi, funded the research project (grant number: BE 153092).

Competing interests None declared.

Patient consent for publication Not required.

Ethics approval The research was approved by the Institutional Ethics Committee, RIMS, Ranchi, Jharkhand, India.

Provenance and peer review Not commissioned; externally peer reviewed. 
Data availability statement Data are available upon reasonable request. Data may be obtained from a third party and are not publicly available.

Open access This is an open access article distributed in accordance with the Creative Commons Attribution Non Commercial (CC BY-NC 4.0) license, which permits others to distribute, remix, adapt, build upon this work non-commercially, and license their derivative works on different terms, provided the original work is properly cited, appropriate credit is given, any changes made indicated, and the use is non-commercial. See: http://creativecommons.org/licenses/by-nc/4.0/.

\section{ORCID iD}

Dewesh Kumar http://orcid.org/0000-0001-5356-801X

\section{REFERENCES}

1 Menon P, Headey D, Avula R, et al. Understanding the geographical burden of stunting in India: a regression-decomposition analysis of district-level data from 2015-16. Matern Child Nutr 2018;14:e12620.

2 Leiva Plaza B, Inzunza Brito N, Pérez Torrejón H. Algunas consideraciones sobre el impacto de la desnutricion en el desarrollo cerebral, inteligencia y rendimiento escolar [The impact of malnutrition on brain development, intelligence and school work performance]. Arch Latinoam Nutr 2001;51:64-71.

3 Shenkin A. Micronutrients in health and disease. Postgrad Med J 2006;82:559-67.

4 Gonmei Z, Toteja GS. Micronutrient status of Indian population. Indian J Med Res 2018:148:511-21.

5 Kapil U, Pradhan R. Integrated child development services scheme (ICDs) and its impact on nutritional status of children in India and recent initiatives. Indian J Public Health 1999;43:21-5.

6 Department of School Education \& Literacy, Ministry of Human Resource Development, Govt. of India. Mid-day meal scheme, 2019. Available: https://mhrd.gov.in/mid-day-meal

7 Leighton G, Clark ML. Milk consumption and the growth of school children: second preliminary report on tests to the Scottish board of health. Br Med J 1929;1:23-5.

8 Rahmani K, Djazayery A, Habibi MI, et al. Effects of daily milk supplementation on improving the physical and mental function as well as school performance among children: results from a school feeding program. J Res Med Sci 2011;16:469-76.

9 Marsh S, Jiang Y, Carter K, et al. Evaluation of a free milk in schools program in New Zealand: effects on children's milk consumption and Anthropometrics. J Sch Health 2018;88:596-604.

10 Lien DTK, Nhung BT, Khan NC, et al. Impact of milk consumption on performance and health of primary school children in rural Vietnam. Asia Pac J Clin Nutr 2009;18:326-34.

11 Thompson B, Amoroso L. Combating micronutrient deficiencies: food-based approaches. Wallingford: CABI, FAO, 2011.

12 Kristjansson EA, Robinson V, Petticrew M, et al. School feeding for improving the physical and psychosocial health of disadvantaged elementary school children. Cochrane Database Syst Rev 2007;1:CD004676.

13 Gaucheron F. Milk and dairy products: a unique micronutrient combination. J Am Coll Nutr 2011;300::400S-9. 5.

14 Bonjour J-P, Lecerf J-M. Dairy micronutrients: new insights and health benefits. Introduction. J Am Coll Nutr 2011;30:399S.

15 Flynn A. Minerals and trace elements in milk. Adv Food Nutr Res 1992;36:209-52.

16 Thorning TK, Raben A, Tholstrup T, et al. Milk and dairy products: good or bad for human health? an assessment of the totality of scientific evidence. Food Nutr Res 2016;60:32527.

17 Kujur A, Kumar D, Kumar C, et al. Socio-Demographic differentials of cognitive development and nutrition among school children: evidence from the tribal areas of Jharkhand, India. Int $J$ Adolesc Med Health 2020;33. doi:10.1515/ijamh-2018-0219. [Epub ahead of print: 01 May 2020].

$18 \mathrm{WHO}$. Hemoglobin concentrations for the diagnosis of anemia and assessment of severity. Geneva: WHO, 2011.

19 FAO. India at a glance, 2020. Available: http://www.fao.org/india/faoin-india/india-at-a-glance/en/

20 Paul TV, Thomas N, Seshadri MS, et al. Prevalence of osteoporosis in ambulatory postmenopausal women from a semiurban region in southern India: relationship to calcium nutrition and vitamin D status. Endocr Pract 2008;14:665-71.

21 Puri S, Marwaha RK, Agarwal N, et al. Vitamin D status of apparently healthy schoolgirls from two different socioeconomic strata in Delhi: relation to nutrition and lifestyle. Br J Nutr 2008;99:876-82.
22 Goswami R, Kochupillai N, Gupta N, et al. Presence of 25(OH) D deficiency in a rural North Indian village despite abundant sunshine. $J$ Assoc Physicians India 2008;56:755-7.

23 Vupputuri MR, Goswami R, Gupta N, et al. Prevalence and functional significance of 25 -hydroxyvitamin $D$ deficiency and vitamin $D$ receptor gene polymorphisms in Asian Indians. Am J Clin Nutr 2006:83:1411-9.

24 Kapil U, Pandey RM, Goswami R, et al. Prevalence of vitamin D deficiency and associated risk factors among children residing at high altitude in Shimla district, Himachal Pradesh, India. Indian J Endocrinol Metab 2017;21:178-83.

25 Basu S, Gupta R, Mitra M, et al. Prevalence of vitamin D deficiency in a pediatric hospital of eastern India. Indian J Clin Biochem 2015;30:167-73.

26 Angurana SK, Angurana RS, Mahajan G, et al. Prevalence of vitamin $D$ deficiency in apparently healthy children in North India. $J$ Pediatr Endocrinol Metab 2014;27:1151-6.

27 Mourad G, Bettache G, Samir M. Composition and nutritional value of raw milk. Bio Sci Pharm Res 2014;2:115-22.

28 Aparna P, Muthathal S, Nongkynrih B, et al. Vitamin D deficiency in India. J Family Med Prim Care 2018;7:324-30.

29 Matte JJ, Guay F, Girard CL. Bioavailability of vitamin $B_{12}$ in cows milk. Br J Nutr 2012;107:61-6.

30 United States Department of Agriculture (USDA). Composition of foods, raw, processed, prepared. Beltsville: USDA (Agricultural Research Service), 2004. https://www.ars.usda.gov/ARSUserFiles/ 80400535/DATA/sr17/sr17_doc.pdf

31 Health Canada. Food and nutrition, dietary reference intakes, tables, 2006. Available: http://www.hc-sc.gc.ca/fn-an/nutrition/reference/ table/index-eng.php

32 Naik S, Bhide V, Babhulkar A, et al. Daily milk intake improves vitamin B-12 status in young vegetarian Indians: an intervention trial. Nutr $J$ 2013;12:136.

33 Tucker KL, Rich S, Rosenberg I, et al. Plasma vitamin B-12 concentrations relate to intake source in the Framingham offspring study. Am J Clin Nutr 2000;71:514-22.

34 Vogiatzoglou A, Smith AD, Nurk E, et al. Dietary sources of vitamin B-12 and their association with plasma vitamin B-12 concentrations in the general population: the Hordaland homocysteine study. Am J Clin Nutr 2009;89:1078-87.

35 Nogalska A, Momot M, Sobczuk-Szul M. Calcium and magnesium content in the milk of high yielding cows. J. Elem 2016;22:809-15.

36 Caroli A, Poli A, Ricotta D, et al. Invited review: dairy intake and bone health: a viewpoint from the state of the art. J Dairy Sci 2011;94:5249-62.

37 Keller JL, Lanou A, Barnard ND. The consumer cost of calcium from food and supplements. J Am Diet Assoc 2002;102:1669-71.

38 Weaver CM, Proulx WR, Heaney R. Choices for achieving adequate dietary calcium with a vegetarian diet. Am J Clin Nutr 1999;70:543s-8.

39 Hong H, Kim E-K, Lee J-S. Effects of calcium intake, milk and dairy product intake, and blood vitamin D level on osteoporosis risk in Korean adults: analysis of the 2008 and 2009 Korea National health and nutrition examination survey. Nutr Res Pract 2013;7:409-17.

40 Kouvelioti R, Josse AR, Klentrou P. Effects of dairy consumption on body composition and bone properties in youth: a systematic review. Curr Dev Nutr 2017;1:e001214.

41 Ziegler EE. Consumption of cow's milk as a cause of iron deficiency in infants and toddlers. Nutr Rev 2011;69 Suppl 1:S37-42.

42 Levy-Costa RB, Monteiro CA. Consumo de leite de vaca e anemia na infância no Município de São Paulo [Cow's milk consumption and childhood anemia in the city of São Paulo, southern Brazil]. Rev Saude Publica 2004;38:797-803.

43 Oliveira MA, Osório MM. Consumo de leite de vaca e anemia ferropriva na infância [Cow's milk consumption and iron deficiency anemia in children]. J Pediatr 2005;81:361-7.

44 Jackson LS, Lee K. The effect of dairy products on iron availability. Crit Rev Food Sci Nutr 1992;31:259-70.

45 Oski FA. Is bovine milk a health hazard? Pediatrics 1985;75:182-6.

46 Turnlund JR, Smith RG, Kretsch MJ, et al. Milk's effect on the bioavailability of iron from cereal-based diets in young women by use of in vitro and in vivo methods. Am J Clin Nutr 1990;52:373-8.

47 Lönnerdal B. Calcium and iron absorption--mechanisms and public health relevance. Int J Vitam Nutr Res 2010;80:293-9.

48 Hahn PF, Whipple GH. Hemoglobin production in anemia limited by low protein intake : influence of iron intake, protein supplements and fasting. J Exp Med 1939;69:315-26. 